\title{
Efforts To Increase Interest In Paying Zakat With Knowledge And Self-Awareness
}

\author{
Dewi Rafiah Pakpahan ${ }^{1 *}$, Ahmad Fadli ${ }^{2}$, Martin $^{3}$, Maya Andiriani ${ }^{4}$, Sabaruddin Chaniago ${ }^{5}$ \\ ${ }^{1}$ Accounting Study Program, STIE Mahkota Tricom Unggul \\ ${ }^{2}$ Management Study Program, STIE Mahkota Tricom Unggul \\ ${ }^{3}$ Computerized Accounting Study Program, LP3M Superior Polytechnic \\ ${ }^{4}$ Management Study Program, SITE Professional Indonesia \\ ${ }^{5}$ Computerized Accounting Study Program, Superior Polytechnic LP3M \\ *Corresponding author: \\ Email: dwirapakpahan@gmail.com
}

\begin{abstract}
The concentration of this research focuses on efforts to increase interest in paying zakat which is influenced by muzak knowledge and self-awareness. The National Zakat Agency of North Sumatra was chosen as the research site where 100 muzak were used as the population and the research sample with accidental sampling technique. Data collection uses a questionnaire where the measurement scale uses a Likert scale. The results of the study prove that knowledge and self-awareness have a significant influence in increasing muzakki's interest in paying zakat. Then this self-awareness has a dominant influence when compared to the knowledge possessed by muzak, especially in increasing their interest in paying zakat.
\end{abstract}

Keywords: Knowledge, Awareness, Interest

\section{INTRODUCTION}

Zakat is one of the mandatory worship for Muslims can be a financial instrument that can reduce the gap between the rich and the poor. As a country with a Muslim majority population, Indonesia has a large zakat potential [1]. The number of amil zakat institutions that have developed in Indonesia, not only increases the potential of zakat but also the number of zakat collections every year which has increased. The amount of zakat collection in Java is different from the amount of zakat collection outside Java. This is because the majority of religions are embraced by the local population. Apart from religion, another problem is work experience and income. In other cities, the income received is very high but the expenditure is also very high. In addition to problems outside Java, a small problem around is the income received. If the income received is high and there is a lot of work experience, it will make a person more grateful and will share it with others [2]. Bazas North Sumatra has the task of collecting, distributing, and utilizing zakat, the community can form the Amil Zakat Institution (LAZ) whose purpose is to collect, distribute, and utilize zakat. In managing zakat, the LAZ must be able to apply three aspects, namely trustworthy, professional, and transparent. According to the North Sumatra provincial government in the North Sumatra provincial secretariat's public relations and protocol bureau, (2019) the potential for zakat collection in North Sumatra province can reach 3 trillion per year compared to the number of residents in North Sumatra, but from data taken from financial reports North Sumatra national amil zakat agency for the last 5 years wherein 2014 the percentage was $19 \%$, in 2015 it increased by $23 \%$, in 2016 it decreased at $4 \%$, in 2017 it increased by $36 \%$ and in 2018 it increased at $29 \%$.

The average increase in zakat receipts in the province of North Sumatra is at $21 \%$, this is a good increase in awareness for the community in issuing zakat, but in 2016 there was a decline in receipts of 4\% even though in other years there was an increase. problems in public awareness in issuing zakat in the province of North Sumatra.Interest in paying zakat is an impulse that exists in a muzak of interest, desire, and belief in paying zakat [3]. Furthermore, the encouragement of awareness of paying zakat can come from within a muzak as well as an invitation from his closest friends [4]. It is hoped that more and more muzak who have a strong desire to pay zakat will be able to assist the government in reducing the level of poverty in Indonesia. [5]. In the future, zakat is considered to be able to help the role of taxes and even replace the role 
of taxes in the welfare of the nation's life. In addition to the benefits for the country, zakat can also make Indonesia's name in the international world better [6]. The low interest of someone who is obliged to pay zakat to distribute zakat malls or professional zakat to zakat management institutions is the cause of the gap between the potential amount of zakat and the nominal zakat received. The less than the optimal amount of zakat collected is caused by several things, including; First, ignorance of the obligation to pay zakat. second, unwillingness to pay zakat. third, distrust of zakat management institutions [7]. The knowledge possessed by a consumer, of course, the company will easily explain the value of the benefits of a product and service. It will be very difficult for marketers to deal with consumers who have low knowledge if the product marketers offer is more related to knowledge [8]. The knowledge possessed by muzak will have a major influence in increasing interest in paying zakat [1].

People who have an understanding of the benefits of paying zakat and the positive impact of paying zakat reflect that they already have good knowledge of an obligation that must be fulfilled. [3]. Then knowledge of zakat can be interpreted as public knowledge about zakat, the purpose, and benefits of zakat, the impact that will be obtained from paying zakat which will give birth to a culture of community zakat as an obligation that must be fulfilled [9]. For muzak, knowledge about paying zakat is very important. This is so that muzak knows well when to pay and how much zakat must be paid. Previous research shows that when the knowledge of a muzak is getting better, it will increase interest in paying zakat [10][11][12].As a muzak, you should have self-awareness in paying zakat. The self-awareness of a muzak must continue to be improved. Remember that it may be possible for a muzak to forget when and how much zakat he has to pay. So this step is intended to help the muzak that in every property there is zakat that must be issued. The results of previous studies show that when self-awareness is increased, it will increase interest in paying zakat [13][14].

\section{METHODS}

This research approach is based on a quantitative approach. Quantitative research methods can be interpreted as research methods based on the philosophy of positivism, used to examine certain populations or samples, sampling techniques are generally carried out randomly, data collection uses research instruments, data analysis is quantitative/statistical with the aim of testing hypotheses that have been established [15]. The population used in this study is Muzakki who pay zakat in the North Sumatra Baznas as many as 100 people. While the sampling technique uses accidental sampling. Where 100 muzakki who have paid zakat in North Sumatra Baznas are sampled in this study. The data collection technique in this study is by distributing a questionnaire (questionnaire) with a Likert scale. Data analysis used multiple linear regression analysis. Finally, data analysis uses factor analysis with the help of the Amos 22 application program.

\section{RESULT AND DISCUSSION}

\section{Respondent's Description}

Characteristics of Respondents by Gender

The general description of the respondents in this study is Muzakki Baznas North Sumatra by gender, can be seen in the picture below:

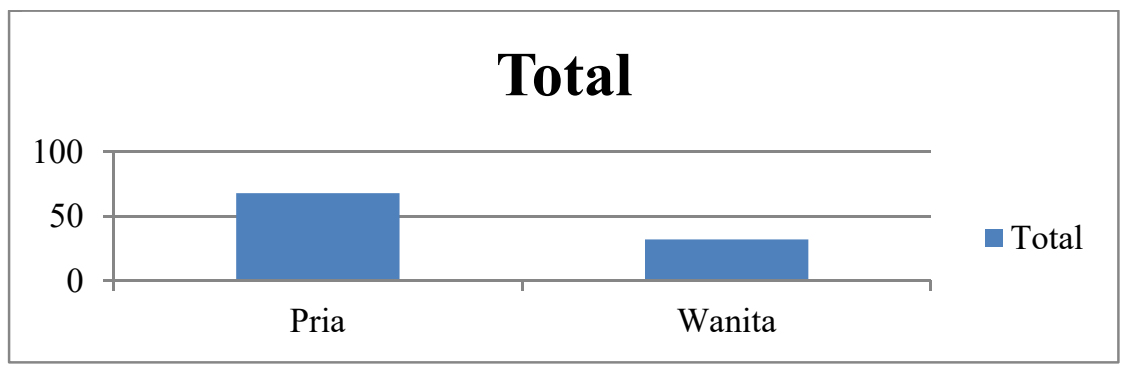

Fig 1. Characteristics of Respondents by Gender 
The results of the research based on gender in the picture above show that the respondents based on gender are Muzakki Baznas North Sumatra out of 100 respondents, the most is Muzakki who is female as many as 32 respondents (32\%) while men amounting to 68 people $(68 \%)$.

\section{Characteristics of Respondents Based on Education Level}

The general description of respondents in this study is Muzakki Baznas North Sumatra based on education level, can be seen in the picture below:

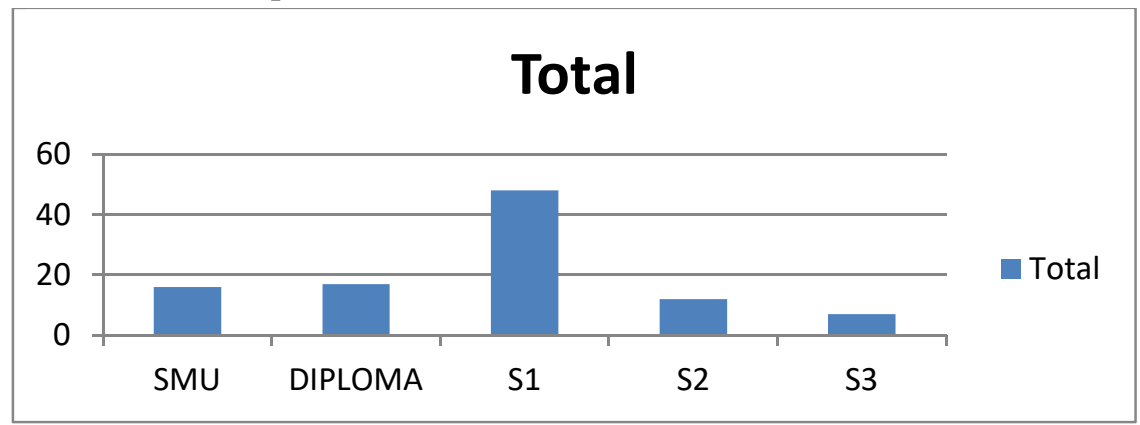

Fig 2. Characteristics of Respondents Based on Education Level

The results of the study based on gender in Table IV.2 show that the respondents based on the education level of Muzakki Baznas North Sumatra out of 100 respondents, the most is Muzakki with high school education as many as 100 respondents (100\%).

\section{Characteristics of Respondents Based on Age}

General description of respondents in this study is Muzakki Baznas North Sumatra by age, can be seen in the following picture:

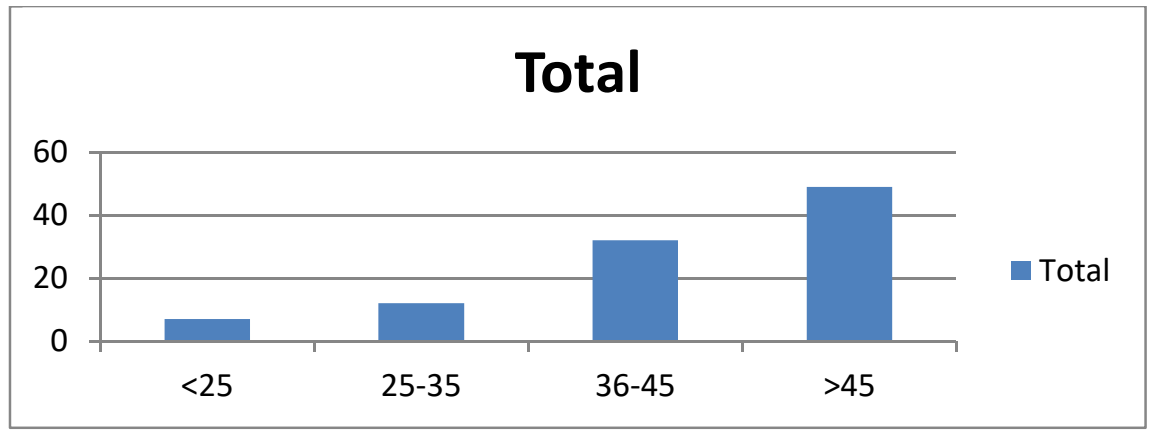

Fig. 3 Characteristics of Respondents by Age

The results of the study by age level are in Table IV.3. showed that from the number of respondents studied as many as 210 people aged Muzakki Baznas North Sumatra where age $<25$ years were 7 respondents (7\%), age 25-35 years were 12 respondents (12\%), aged 36-45 years were 32 respondents $(32 \%)$ and age $>45$ years as many as 49 respondents $(49 \%)$.

\section{The Effect of Knowledge on Interest in Paying Zakat}

Based on the results of the study, it can be seen that the value of tcount $>$ table $(2,037>1,993)$ or the sign value of $t$ for the work discipline variable $(0.000<0.05)$. Based on the results obtained, H1 is accepted, and $\mathrm{HO}$ is rejected for the knowledge variable. Thus, partial knowledge has a positive and significant effect on interest in paying zakat. The results of this study are in line with [1][3][6] which states that knowledge has a positive effect on interest in paying zakat. This shows that when the knowledge of the muzakki is getting better about the obligation to pay zakat, this will have an impact on increasing interest in paying zakat.

\section{The Effect of Self-Awareness on Interest in Paying Zakat}

Based on the results of data processing, it is obtained that the value of tcount $>$ table $(15.262>1.993)$ or the sign value of $\mathrm{t}$ for the work discipline variable $(0.000<0.05)$. Based on the results obtained, $\mathrm{H} 1$ is accepted, and H0 is rejected for the self-awareness variable. Thus, partially self-awareness has a positive effect on interest in paying zakat. The results of this study are in line with [16][17][18] which states that selfawareness has a positive and significant effect on interest in paying zakat. This shows that when the self- 
awareness of the muzakki is getting better about the obligation to pay zakat, this will have an impact on increasing interest in paying zakat.

\section{The Effect of Knowledge and Self-Awareness on Interest in Paying Zakat}

Based on the results of data analysis, it shows that the Fount value is 136.204 and the Fable value is 3.09, which means Fcount $>$ Ftable and the significant value is $0.000<0.05$. This shows that knowledge and self-awareness have a positive effect on interest in paying zakat. The results of this study are in line with research [11][19] which states that knowledge and self-awareness have a positive and significant effect on interest in paying zakat. This shows that when knowledge and self-awareness are increased, it will increase interest in paying zakat.

\section{CONCLUSION}

The conclusion that can be drawn is that knowledge and self-awareness in this study are both partially and simultaneously proven to have a significant influence in increasing muzakki's interest in paying zakat, especially in the North Sumatra Baznas. This proves that when the North Sumatra Baznas are able to maximize knowledge and self-awareness, it has the potential to increase zakat income to be collected at the North Sumatra Baznas.

\section{ACKNOWLEDGMENTS}

The authors thank Baznas Sumut for providing the necessary permissions and data sources. In addition, the authors would like to thank in particular the Director of Research and Community Service (DRPM) who has provided research funding support through the novice lecturer grant research program.

\section{REFERENCES}

[1] A. A. I. Yuliafitri, "Pengaruh Pengetahuan, Kepercayaan Dan Pelayanan Lembaga Amil Zakat Terhadap Minat Membayar Zakat Di Lembaga Amil Zakat," ISEI Account. Rev., vol. IV, no. 1, pp. 8-13, 2020.

[2] L. M. K. A. Arilia, "Pengaruh Religiusitas Dan Demografi Santri Pondok Pesantren Jagad Alimussirry Terhadap Minat Membayar Zakat Melalui Lembaga Amil Zakat,” J. Ekon. Islam, vol. 2, no. 2, pp. 62-71, 2019.

[3] Z. H. I. Kurniawan, "Pengaruh Pengetahuan Zakat Dan Kepercayaan Kepada Baznas Kabupaten Kuantan Singingi Terhadap Minat Muzakki Membayar Zakat,” J. Tabarru' Islam. Bank. Financ., vol. 3, no. 1, pp. 3040, 2020.

[4] E. M. Nur, "Pengaruh Promosi dan Kualitas Layanan terhadap Minat Masyarakat Membayar Zakat," AiMuqayyad, vol. 3, no. 2, pp. 126-135, 2020.

[5] E. D. P. F. Setiawan, "Pengaruh Pendapatan Terhadap Intensi Membayar Zakat Profesi (Studi Kasus Di Kabupaten Ponorogo)," in Seminar Nasional dan Call For Paper III, 2018, pp. 121-129.

[6] A. S. N. A. Nurkhin, "Pengaruh religiusitas, pendapatan, pengetahuan zakat terhadap minat membayar zakat profesi melalui Baznas dengan faktor usia sebagai variabel moderasi," Econ. Educ. Anal. J., vol. 8, no. 3, pp. 955-966, 2019.

[7] D. Priliastuti, "Pengaruh pendapatan, kepercayaan dan religiusitas terhadap minat untuk membayar zakat penghasilan,” J. Econ. Res. Policy Stud., vol. 1, no. 1, pp. 12-24, 2021.

[8] N. D. T. Syaifullah, Perilaku Konsumen (Studi Dalam Pemilihan Perguruan TinggI. Yogyakarta: Nuta Media, 2021.

[9] M. R. A. Fadli, "Pengaruh Pengetahuan Zakat, Pendapatan Dan Kepercayaan Muzakki Terhadap Minat Pelaku Umkm Untuk Membayar Zakat Niaga Di Organisasi Pengelola Zakat Kota Bengkulu,” J. Akunt., vol. 11, no. 1, pp. 67-80, 2021.

[10] N. A. Rakhmania, "Pengaruh Pendapatan, Religiusitas, Kepercayaan Dan Pengetahuan Terhadap Minat Muzakki Mengeluarkan Zakat Melalui Lembaga Amil Zakat Di Kota Malang,” Universitas Brawijaya, 2018.

[11] M. A. Fahad, "Pengaruh Kepercayaan Terhadap Baznas, Pendapatan Dan Pengetahuan Zakat Terhadap Minat Masyarakat Membayar Zakat Mal Di Kabupaten Bojonegoro,” Universitas Brawijaya, 2019.

[12] M. Fakhruddin, "Analisis Pengaruh Tingkat Pengetahuan Zakat, Tingkat Religiusitas, Tingkat Pendapatan, Dan Tingkat Kepercayaan Kepada BAZNAS Terhadap Minat Membayar Zakat Profesi Pada Pekerja (Studi Kasus Pekerja Di DKI Jakarta),” Universitas Diponegoro, 2016.

[13] P. Rusdianto, "Pengaruh Promosi, Kualitas Pelayanan dan Religiusitas terhadap Minat Masyarakat Menjadi 
Muzakki Pada Lembaga Amil Zakat (LAZ) Dompet Dhuafa,” Universitas Islam Negeri Syarif Hidaahtullah, 2016.

[14] Y. Zikriyah, "Pengaruh Tingkat Kesadaran masyarakat Kelurahan Lenteng Agung Terhadap Implementasi Zakat Profesi Tahun 2017,” 2017.

[15] Sugiyono, Metode Penelitian Kuantitatif, Kualitatif dan R\&D. Bandung: Alfabeta, 2019.

[16] H. R. H. G. H. D. H. Ritonga, "Analisis Tingkat Kesadaran Masyarakat Kecamatan Medan Baru Dalam Membayar Zakat,” J. Ekon. Dan Keuang., vol. 3, no. 7, pp. 490-504, 2015.

[17] E. Y. Nasution, "Pengaruh Pendidikan , Pendapatan dan Kesadaran Terhadap Minat Masyarakat Membayar Zakat di Badan Amil Zakat Nasional ( BAZNAS ): Studi Kasus Kota Medan,” J. Ilmu Ekon. dan Stud. Pembang., vol. 17, no. 2, pp. 147-158, 2017.

[18] I. Kamil, "The Effect of Zakat as A Reduction Of Taxed Income And Self Awareness Of Personal Personal Tax Payer (WPOP) Compliance," in ICETLAWBE, 2020, pp. 1-8.

[19] M. M. N. Zulfahmi, "Pengaruh Pengetahuan, Pendapatan, dan Kepercayaan, Terhadap Minat Muzakki dalam Membayar Zakat Di Baitul Mal Kota Lhoksemawe,” J. Ekon. Reg. Unimal, vol. 01, no. 3, pp. 89-99, 2018. 